\title{
Wykorzystanie aspektów konstruktywizmu w kształtowaniu świadomości ekologicznej
}

\author{
Use of Aspects of Constructivism in Shaping Ecological Awareness
}

\author{
Elżbieta Buchcic \\ Instytut Pedagogiki, Uniwersytet Jana Kochanowskiego w Kielcach \\ ORCID: https://orcid.org/0000-0002-2391-6340•ebuchcic2@wp.pl \\ Zgłoszono: 27.10.2020; zrecenzowano: 4.01.2021; zaakceptowano do druku: 14.01.2021
}

Streszczenie: W dzisiejszych czasach pedagogiczne aspekty kształtowania świadomości ekologicznej społeczeństwa to temat bardzo istotny w kontekście negatywnych zmian zachodzących w środowisku przyrodniczym i rosnącej wciąż antropopresji. Ale jest to zagadnienie bardzo obszerne, które trzeba rozpatrywać wieloaspektowo, z punktu widzenia wielu dziedzin naukowych - między innymi również pedagogiki, psychologii, socjologii, filozofii - na bazie nauk przyrodniczych. Zawsze w podejmowanych przedsięwzięciach warto uwzględnić, jako priorytetowy wątek, edukację formalną i nieformalną całego społeczeństwa, a nie tylko dzieci i młodzieży, ponieważ to dorośli zarządzają środowiskiem. Należy również pamiętać, że wiedza to nie tylko fakty, zasady i teorie wywodzące się z obserwacji zjawisk i wydarzeń, lecz także umiejętność racjonalnego wykorzystania i interpretacji tych informacji w życiu codziennym. Dlatego, wykorzystując założenia pedagogiki konstruktywistycznej, można wzbogacić ofertę działań służących kształtowaniu świadomości ekologicznej całego społeczeństwa. Artykuł prezentuje wybrane założenia pedagogiki konstruktywistycznej i możliwości wdrażania jej podczas kształtowania prawidłowych postaw wobec przyrody. Ponieważ warto ciągle poszukiwać odpowiedzi na pytanie, w jaki sposób kształtować świadomość ekologiczną, aby stopniowo zmniejszać nastawienie ludzi na "mieć", a zwiększać na "być". Docenienie wartości przyrody ma również istotne znaczenie dla urzeczywistnienia idei zrównoważonego rozwoju, która jest jedyną nadzieją na "lepsze jutro". Obecnie szczególnym wyznacznikiem ochrony środowiska są podejmowane konkretne działania związane z szeroko rozumianą relacją: człowiek - kultura - natura. Współzależności uwarunkowane są jednak czynnikami wpływu kulturowego na środowisko oraz wpływu środowiska na preferowane wartości.

Słowa kluczowe: wartość, konstruktywizm, konstruktywizm przyrodniczy, świadomość, świadomość ekologiczna

\begin{abstract}
Nowadays, the pedagogical aspects of shaping ecological awareness in society are a very important topic in the context of negative changes taking place in the natural environment, and the constantly growing anthropo-pressure. However, it is a very broad issue that needs to be considered in many ways, from the point of view of many scientific fields, including pedagogy, psychology, sociology, and philosophy, based on the natural sciences. It is always worth considering as a priority, the formal and informal education of the whole society, and not only children and adolescents, because it is adults who manage the environment. It should also be remembered that knowledge is not only facts, principles, and theories, derived from the observation of phenomena and events, but also the ability to rationally use and interpret this information in everyday life. Therefore, using the assumptions of constructivist pedagogy, it is possible to enrich the offer of activities aimed at shaping the ecological awareness of the entire society. The article presents selected assumptions of constructivist pedagogy, and the possibility of implementing it, while shaping correct attitudes towards nature. It is constantly worth looking for an answer to the question of how to shape ecological awareness, in order to gradually reduce
\end{abstract}


people's attitude to "have" and increase the attitude of "to be". The appreciation of the value of nature is also essential for the realisation of the idea of sustainable development, which is the only hope for a "better tomorrow". Currently, a specific determinant of environmental protection are specific activities related to the broadly understood relationship of man culture - nature. However, the interdependencies are conditioned by factors of cultural influence on the environment, and the influence of the environment on the preferred values.

Keywords: value, constructivism, environmental constructivism, awareness, environmental awareness

\section{Wstęp}

Wszystkim nam marzy się świat, w którym doświadczamy poczucia szczęścia, spokoju, harmonii, komfortu psychicznego i dostatku. W związku z powyższym warto zastanowić się, jakie działania należy podjąć, aby wykształcić prawidłową świadomość ekologiczną społeczeństwa.

Współcześnie edukacja w tym zakresie jest niezwykle ważna. Jej głównym celem powinno być uświadomienie, że człowiek to tylko część przyrody, a jego działania mają nierozerwalny związek ze stanem środowiska. Pomocna w tym przedsięwzięciu może być silnie akcentowana w ostatnich latach edukacja bazująca na teorii konstruktywistycznej. Przecież ciągle trwa poszukiwanie prekursorskich i skutecznych systemów oraz metod wychowawczych. Tworzy się też innowacyjne, ale i wraca do tych, które już sprawdziły się i na stałe zapisały w procesie kształcenia i wychowania w edukacji formalnej, jak również pozaformalnej.

Celem niniejszego opracowania jest, po pierwsze, przypomnienie pokrótce pojęć: świadomość ekologiczna, konstruktywizm przyrodniczy oraz rola konstruktywizmu w nauczaniu. Konteksty tej problematyki odniesione są do informacji zamieszczonych w wybranej literaturze. Kolejny cel to zwrócenie uwagi czytelników na wykorzystanie aspektów konstruktywizmu w kształtowaniu świadomości ekologicznej, ponieważ kwestia ta jest wciąż ważnym zagadnieniem, a dowodów jej aktualności dostarczają nam liczne przesłanki. Konstruktywistyczna teoria kształcenia może być cennym narzędziem, które z powodzeniem warto, a nawet należy wykorzystywać w procesie edukacji, szczególnie nastawionym na podniesienie stanu świadomości społeczeństwa o szeroko rozumianej ochronie środowiska. Ponadto w opracowanym artykule podjęto się próby ukazania i zainteresowania oraz uzasadnienia przydatności konstruktywizmu jako teorii uczenia się w procesie kształtowania świadomości ekologicznej, wykorzystując możliwości edukacji ekologicznej formalnej i nieformalnej.

W przygotowanym materiale zwrócono również uwagę na fakt, że przyroda jest nieodłącznym elementem życia każdego człowieka i powinna stanowić dla niego wartość. Trudno wyobrazić sobie codzienne funkcjonowanie bez wyznaczonych wartości, które mogą być dla jednych ideałem, dla innych zaś celem bądź jeszcze czymś innym, ponieważ wartości mają ogromne znaczenie w ludzkim życiu i postępowaniu. Należy zauważyć, że świat, w którym egzystuje człowiek, jest światem wartości. Dlatego trzeba korzystać z dobrodziejstw przyrody, a zarazem żyć z nią w harmonii. To właśnie człowiek od najdawniejszych czasów miał wpływ na rozwój cywilizacji poprzez ingerencję w środowisko przyrodnicze. Każdy zaś wybór dokonywany przez nas powinien opierać się na uniwersalnych wartościach. Jan Paweł II wskazywał, że człowiek został stworzony do „miłości, pokoju i mądrego władania światem" (Jan Paweł II 2008).

Przygotowany materiał stanowi tylko punkt wyjścia i jest zachętą dla czytelników do podjęcia interdyscyplinarnych badań oraz analiz i dyskusji na temat: w jaki sposób, wykorzystując w praktyce edukacji ekologicznej formalnej i nieformalnej teoretyczne 
założenia pedagogiki konstruktywistycznej, można kształtować świadomość ekologiczną.

\section{1. Świadomość ekologiczna}

Świadomość ekologiczna należy do pojęć wieloznacznych, odnosi się do różnorodnych sytuacji oraz stanów psychicznych i zalicza się do zjawisk o charakterze subiektywnym, które funkcjonują w dwóch sferach: opisowo-technicznej (wiedza i wyobraźnia ekologiczna) i aksjologiczno-normatywnej system wartości i norm, dotyczących relacji społeczeństwo-przyroda, człowiek-środowisko (Górka et al. 2001, 30).

Świadomość ekologiczna to obszar świadomości społecznej w odniesieniu do przyrody. Jest wynikiem procesu socjalizacji człowieka przez całe jego życie. Odzwierciedla się w myśleniu i przeżyciach ludzi, jak również w standardach pojmowania i wartościowania biosfery. W skład świadomości ekologicznej wchodzą określone treści, nastawienia i emocje, które odnoszą się do środowiska naturalnego i są ze sobą wzajemnie powiązane oraz przenikają się z innymi formami świadomości społecznej (Kopczewski et al. 2009, 65).

Świadomość środowiskową rozumieć można w wąskim ujęciu, które sprowadza się do interpretowania tego pojęcia w kategoriach wiadomości, umiejętności i postaw oraz pewnych wyobrażeń o stanie środowiska. Natomiast szerokie ujęcie jest już odbierane jako efekt praktycznego dostrzegania i doceniania ważności związku pomiędzy gospodarczą działalnością społeczeństwa a procesem degradacji, a nawet dewastacji przyrody (Papuziński 2006, 34).

Zgodnie z opinią Zbigniewa Hulla, świadomość ekologiczną można rozpatrywać w dwóch płaszczyznach, którymi są:

- płaszczyzna opisowo-techniczna, odnosząca się do wiadomości ekologicznych i do wyobraźni z nią związaną,

- płaszczyzna aksjologiczno-normatywna, która z kolei bierze pod uwagę wartości regulujące relacje pomiędzy człowiekiem a środowiskiem (Hull 1984, 24-25).
Relacje te, zdaniem autora, będąc dojrzałe, prowadzą do tworzenia etyki ekologicznej. Natomiast proces kształtowania świadomości w tym zakresie ma ścisły związek z wewnętrzną strukturą tej świadomości oraz z motywami zewnętrznymi, które przybierają postać działań edukacyjnych, ruchów społecznych oraz ugrupowań politycznych odwołujących się do ideologii ekologicznej i kontestują one dotychczasowe formy organizacji społeczeństwa.

Beata Nakonieczna twierdzi, że struktura świadomości składa się z trzech poziomów:

- przekonania intuicyjnego,

- przekonania intuicyjnego, które odnosi się jednocześnie do wiedzy na temat tego, w jaki sposób powstają zagrożenia środowiskowe,

- poziomu emocjonalnego (Nakonieczna 2001, 189-19o).

Kompozycja ta wskazuje, że człowiek jest w posiadaniu pewnego przekonania, że środowisko naturalne jest czynnikiem, który determinuje jakość życia. Natomiast w trakcie edukacji i wychowania ludzie uświadamiają sobie, jakie są głębsze związki pomiędzy działalnością wykonywaną przez człowieka a środowiskiem. Im większa świadomość, tym głębsze jest zrozumienie mechanizmów odpowiedzialnych za stan środowiska. Rośnie też poziom emocjonalnego związku z biosferą. Warto pamiętać, że na postać emocjonalnych relacji ma wpływ wiele negatywnych czynników, którymi są pejoratywne następstwa działań człowieka, takie jak katastrofy ekologiczne. Znaczący wpływ mają także czynniki pozytywne, które z kolei są efektem przede wszystkim potrzeb estetycznych.

W rozwijaniu świadomości środowiskowej młodego pokolenia, które w niedalekiej przyszłości ma decydować o losach świata, ważne miejsce zajmuje rodzina. To tu tworzą się podwaliny przyszłych zachowań proekologicznych. To właśnie w rodzinie, zdaniem Ireny Grochowskiej, już od wczesnego dzieciństwa można uczyć się prawdziwej miłości przez okazywanie sobie szacunku, czułości, gotowości do wzajemnego służenia sobie. 
Rodzice, nawet ci bez wiedzy ekologicznej, mogą w wyniku tylko samych działań wychowawczych przygotować dziecko do rozumienia wiadomości pojawiających się w późniejszym procesie edukacji środowiskowej i bogatego w treści merytoryczne kształcenia szkolnego (Grochowska 2006, 424).

Świadomość ekologiczna jest również częścią świadomości społecznej. Według Dariusza Kiełczewskiego świadomość ekologiczna jest rozumiana jako stosunek człowieka do środowiska przyrodniczego, zespół informacji i przekonań na jego temat, a także system wartości, jakim ta osoba kieruje się wobec niego w swoim postępowaniu (Kiełczewski 2001, 163 oraz szerzej na ten temat Papuziński 2006, 33-40). Pojęcie to może być używane w dwóch znaczeniach. W znaczeniu szerszym oznacza całokształt uznawanych idei, wartości i opinii o środowisku przyrodniczym jako miejscu życia i rozwoju człowieka (społeczeństwa), wspólnych dla określonych grup w danym okresie historycznym (Hull 1984, 3). W znaczeniu węższym, bardziej praktycznym, świadomość ekologiczna jest to stan wiedzy, poglądów i wyobrażeń ludzi o roli środowiska w życiu człowieka, jego antropogennym obciążeniu, stopniu wyeksploatowania, zagrożenia i ochrony, w tym także stan wiedzy o sposobach i instrumentach sterowania użytkowaniem i ochroną środowiska (Domka 1998, 89). Dlatego też bardzo często świadomość środowiskową określa się jako implikację świadomości ekologicznej i społecznej (Sasinowski 1997, 110).

Aby świadomość w tym zakresie stała się świadomością społeczną, musi wynikać ze stałego dopływu informacji i przekazywania tradycji ze środowiska lokalnego. Trafny wydaje się w tej kwestii pogląd Tadeusza Pilcha, który uważa, że środowisko lokalne, oprócz zbiorowości lokalnej zamieszkującej niewielki względnie zamknięty obszar, to również cały system instytucji służących organizacji życia zbiorowego, takich jak: kościół, szkoła, instytucje usługowe, oraz urządzenia socjalne lub rekreacyjne i mechanizmy regulujące zachowania jednostkowe i stosunki międzyludzkie, a więc obyczajowość i normy moralne, autorytety i wzory zachowań (Pilch 1993, 156). Warto również pamiętać, że szczególna wspólnota łącząca i integrująca pewne społeczności nie musi być związana z zamieszkiwaniem na wspólnym terenie, ale może opierać się na podzielaniu tych samych wartości, symboli i respektowaniu zasad wzajemnego porozumienia. Rola środowiska lokalnego i jego funkcja wychowawcza zajmują ważne miejsce w kształtowaniu poglądów jednostki.

\section{Konstruktywizm przyrodniczy}

Jak już wcześniej wspomniano, przygotowanie człowieka do aktywnego uczestnictwa i prawidłowego przekształcania rzeczywistości społecznej wymaga kształtowania właściwych postaw, poglądów oraz przekazywania odpowiednich wzorów zachowań. Człowiek bardzo często staje w sytuacji konfliktu między tym, co już wie a tym, co do niego dociera. Dzieje się tak na skutek interakcji ze światem zewnętrznym. Decyduje on wówczas, zgodnie ze swoją wiedzą oraz doświadczeniem, jak zinterpretuje i wyjaśni te informacje (Michalak 2005, 102). A przecież każdy system kształcenia bazuje na określonej teorii rozwoju umysłowego człowieka. Dlatego w ostatnich latach wielki renesans przeżywa konstruktywistyczna teoria rozwoju intelektualnego jednostki ludzkiej zakładająca, że człowiek wnosi osobisty wkład w swój rozwój poznawczy, konstruując w toku własnej aktywności rozumienie świata, który go otacza.

Konstruktywizm jest poglądem zakładającym, że ludzie (aktywnie poznając rzeczywistość, w której funkcjonują) nabywają wiedzę poprzez interakcje z otoczeniem. Jest to jednocześnie teoria uczenia się i zdobywania wiedzy oraz nauczania. W myśl tych założeń odchodzi się od teorii powielania gotowych wzorów i poznawania ułożonych instrukcji na rzecz poszukiwania, modyfikowania, interpretowania i sprawdzania wiadomości przez uczącego się. Uczenie się 
jest więc konstruowaniem własnych struktur wiedzy, a nie przyswajaniem gotowych treści czy szablonów. Jest to teoria, która wspiera aktywizujące podejście do nauczania, traktująca ucznia, jako jednostkę aktywną, nauczyciela zaś jako przewodnika - osobę, której rolą jest organizowanie środowiska uczenia się. Teoria ta wywodzi się z koncepcji piagetowskich (Jean Piaget), myśli Marii Montessori, idei Jana Korczaka, Johna Dewey'a i Lwa Wygotskiego, teorię rozwinął zaś Jerome S. Bruner. Przedstawiciele tego nurtu twierdzą, że ludzie uczą się $\mathrm{w}$ interakcji z otoczeniem, aktywnie konstruują własną wiedzę, wykorzystując wiedzę już posiadaną. Efekty poznania zależą nie tylko od poziomu dojrzałości i systemu bezpośrednich oddziaływań zewnętrznych (nauczanie), lecz przede wszystkim od skali aktywności poznającego.

Natomiast, opierając się na neurobiologicznym podejściu do sposobu funkcjonowania mózgu, konstruktywizm zakłada, że:

- uczymy się, nawiązując interakcje z otoczeniem;

- nasza wiedza to indywidualna KON-STRUKCJA;

- poszerzanie wiedzy odbywa się poprzez przyłączanie nowych elementów do tych, które już posiadamy, zgodnie z zasadami asymilacji i akomodacji.

Dlatego środowiska uczenia się nie wolno ograniczać tylko do systemu oświaty. Ponieważ tworzy go wszystko, co uczestniczy w konstruowaniu nowej wiedzy o świecie, wiedza uprzednia, styl poznawczy uczącego się i relacje między uczącym się a przedmiotem poznania. Nadawanie znaczenia nadchodzącym bodźcom odbywa się w kontekście już posiadanej wiedzy i zdobytych doświadczeń.

Konstruowanie wiedzy wymaga więc następujących po sobie etapów:

- interpretacji;

- reorganizacji;

- transformacji;

- uogólniania nadchodzących informacji.

Warto również pamiętać, że konstruktywizm proponuje oparcie kształcenia na eksperymentowaniu oraz poszukiwaniach ukierunkowanych pomysłami uczniów. W poznawaniu wiedzy istotne jest także stawianie atrakcyjnych dla nich problemów oraz tworzenie uczniowskich modeli i hipotez. Zaleca jednocześnie zajmowanie się zagadnieniami związanymi z codziennym życiem młodych ludzi, traktowanymi holistycznie, z uwzględnieniem wstępnego zasobu ich wiedzy i doświadczeń. Rolą uczących powinno być stwarzanie uczniom możliwości podejmowania działań poznawczych oraz budowanie pomostów pomiędzy potocznym rozumieniem danego problemu a rozumieniem bardziej złożonym.

\section{Konstruktywizm w nauczaniu}

Skuteczne nauczanie to przede wszystkim rozbudzanie ciekawości poznawczej oraz tworzenie sytuacji, w których uczeń jest zaangażowany i aktywny. To nie powielanie informacji, lecz ich przetwarzanie, a następnie wnioskowanie sprawiają, że efektywnie i trwale zapisujemy nowe dane w strukturach pamięci. Dlatego konstruktywistyczne kształcenie zasadniczo zmienia relacje w układzie uczeń - nauczyciel. Zadaniem nauczyciela jest planowanie i organizowanie właściwego środowiska uczenia. A w centrum procesu kształcenia znajduje się uczeń, który aktywnie tworzy własną wiedzę.

U podstaw konstruktywistycznej teorii kształcenia leżą następujące założenia (Śniadek 1997, 43-44):

- uczenie się zależy od posiadanej wiedzy i wyobrażeń dziecka;

- uczniowie posiadają bogatą wiedzę wstępną zdobytą w kontakcie z przyrodą, społeczeństwem i środkami masowego przekazu;

- każdy uczeń indywidualnie tworzy swoją wiedzę;

- konstruowanie znaczeń i pojęć jest ciągłym, aktywnym procesem, który powiązany jest z wiedzą wyjściową;

- nauczanie powoduje pojęciowe zmiany i reorganizację dotychczasowej wiedzy;

- uczniowie są odpowiedzialni za własną wiedzę. 
O powodzeniu takich zajęć decyduje wiele zmiennych. Natomiast głównym środkiem prowadzącym do tego celu jest odkrywanie i stymulowanie, przy aktywnym udziale uczniów i nauczyciela, którego uczniowie starają się obserwować i naśladować.

Jak zaznacza Bogusław Śliwierski (2016), w świetle konstruktywizmu proces kształcenia musi zapewniać takie warunki uczącym się, aby mogli oni tworzyć i rozwijać wiedzę własną. Pozwoli im to na lepsze jej zrozumienie, a w rezultacie doskonalsze poznanie świata, w którym znajduje ona swoje zastosowanie. Należy pamiętać, że fundamentalną zasadą konstruktywizmu jest aktywne oraz podmiotowe konstruowanie wiedzy przez osobę ją poznającą.

Konstruktywiści szczególnie mocno akcentują konieczność osobistego zaangażowania się $\mathrm{w}$ proces poznawania, ponieważ wiedzę konstruuje się aktywnie, poznając swoje otoczenie. Uczenie się, jak twierdzą konstruktywiści, jest procesem budowania nowego zasobu wiadomości na bazie doświadczeń i informacji, które jednostka już posiada. Uprzednia wiedza staje się zawsze punktem odniesienia przy rozkodowywaniu i zapamiętywaniu nowych informacji. Konstruktywiści uważają, iż uczenie się przy wsparciu osoby kompetentnej jest o wiele bardziej efektywne. Odpowiednie zrozumienie i wsparcie powoduje, że osiąga się znacznie więcej, niż mogłoby się to uczynić samodzielnie (Michalak 2005, 101). Efekty poznania zależą za głównie od skali aktywności poznającego, jak również od poziomu jego dojrzałości oraz systemu bezpośrednich oddziaływań zewnętrznych. Człowiek musi być aktywny i twórczy, wówczas taka edukacja przyniesie zadowalające rezultaty. Założenia konstruktywizmu realizowane w procesie edukacji dotyczą głównie umiejętności uczenia się, a nie tylko przekazywania treści. Natomiast możliwości pedagogiki konstruktywistycznej pobudzają do odejścia od tradycyjnego modelu nauczania. Dlatego też należy przeorganizować sytuację dydaktyczną w odniesieniu do definiowania wiedzy, postępu oraz sposobu poznawania rzeczywistości i relacji pomiędzy nauczającym a uczącym się.

Piotr Bołtuć uważa, że podstawę teoretyczną przyjmowania w edukacji modelu konstruktywistycznego stanowi przekonanie, że wiedza jest dzisiaj tak złożona, iż nauczyciel nie może w sensie ścisłym „nauczać" - może jedynie wspierać uczniów indywidualnie $\mathrm{w}$ ich poszukiwaniu i dochodzeniu do wiedzy, albo czynić to w ramach pracy grupowej (Bołtuć 2011, 48). Dlatego placówki oświatowe powinny przestać być tylko mentorem wykładającym zawiłe treści, a stać się współuczestnikami sytuacji poznawczych. Toteż, aby zrozumieć przyrodę i zjawiska w niej zachodzące, należy uświadomić sobie, że jesteśmy jej częścią, nie żyjemy obok niej ani ponad nią. Z uwagi na fakt, iż duży wpływ na ukierunkowanie naszego myślenia ma edukacja i wychowanie szkolne, pedagogika konstruktywistyczna daje nam możliwość zgłębienia tajników przyrody.

Twórcy i zwolennicy konstruktywistycznej teorii wiedzy i poznawania uważają, iż wiedza jest indywidualnie konstruowana w społecznym kontekście. Natomiast uczenie się jest ciągłym procesem konstruowania, interpretowania i modyfikowania osobistych reprezentacji rzeczywistości, które opierają się na indywidualnych doświadczeniach. Owe doświadczenia zdobywane są podczas działania. Opisują one zatem wiedzę w kategoriach osobistych jako konstrukcję umysłu ludzkiego, która powstaje w dynamicznym procesie nadawania osobistego sensu i rozumienia ciągle zmieniającej się rzeczywistości (Michalak 2005, 102).

W obecnych czasach, w celu podniesienia jakości kształcenia przyrodniczego warto opracować konstruktywistyczną strategię inicjowania aktywności społeczeństwa w kontekście podejmowanych działań prośrodowiskowych.

Fazy konstruktywistycznego modelu edukacji ekologicznej - propozycja analizy niezbędnych uwarunkowań:

1. Orientacja polega na wprowadzeniu społeczeństwa w zagadnienie i wywo- 
łaniu jego zainteresowania i ciekawości, a w konsekwencji motywacji wewnętrznej do kształtowania własnego aksjologicznego paradygmatu przyrody.

2. Diagnozowanie zasobu wiadomości uprzedniej. Jest to etap ujawniania wstępnych pomysłów, wiedzy i doświadczeń, a więc tego, co uczeń już wie, zna i potrafi w związku z przedmiotem poznania. Takie rozpoznanie niezbędne jest zarówno dla uczącego się, jak i animatora działań promujących przyrodę jako wartość. Należy również ustalić, jakie konstrukcje (reguły, generalizacje) posiada uczący się w odniesieniu do dyskutowanych treści. Według założeń konstruktywizmu to stadium dostrzegania przez uczących się rozbieżności, konfliktu między tym co już wiedzą a bodźcami do nich napływającymi (przeżywanie konfliktu poznawczego zwykle jest pierwszym krokiem do rozwoju intelektualnego człowieka).

3. Restrukturyzacja wiedzy jest fazą włączania nowych informacji do uprzedniej wiedzy i tworzenia jej nowej struktury. Można uznać, że jest to sedno zainicjowanego procesu kształcenia. Wprowadzenie do procesu poznania nowych doświadczeń, dzięki którym dokonuje się modyfikacja dotychczasowej wiedzy. Należy tego dokonać, angażując zainteresowanych w różnorodne działania badawcze, jak np.: obserwacja zjawisk, eksploracja, poszukiwanie informacji z różnych mediów. Podjęte przedsięwzięcia umożliwiają samodzielne odkrycie nowych faktów, spostrzeżeń, informacji, zależności, a także sprzyjają zmianie poglądów oraz formowaniu się prekursorskiej wiedzy.

4. Konieczność nabywania i stosowania nowych wiadomości oraz umiejętności odbywa się w różnorodnym i naturalnym kontekście, bliskim rzeczywistości: autentyczne zadania, czynności i cele służą zdobywaniu najbardziej realistycznych praktyk. Działania te rozwijają odpowiedzialność za najbliższe otoczenie, gdyż autentyczna aktywność wypływa z ich rzeczywistych potrzeb i doświadczeń dnia codziennego.

Przegląd zmian to etap pomysłów i poglądów zdobytych w wyniku podejmowanych działań i porównywania ich z wiedzą uprzednią. Zachodzi wówczas sprzężenie zwrotne między wiedzą wyjściową a wiedzą nową, uczestnicząca zaś $\mathrm{w}$ tym procesie osoba uświadamia sobie zmianę w spostrzeganiu problemu. Daje to jej zadowolenie i poczucie sprawstwa oraz przyczynia się do rozwijania wiary we własne możliwości, która wypływa z realizacji trudnych zadań zakończonych sukcesem (Buchcic 2017, 266).

Oparty na zasadach konstruktywizmu sposób działania jest przede wszystkim procedurą aktywnego tworzenia własnej wiedzy. Pomocne w tym mogą być różne placówki i instytucje działające $\mathrm{w}$ ramach edukacji ekologicznej formalnej i nieformalnej.

\section{Edukacja ekologiczna formalna i nieformalna}

Priorytetowym zadaniem skutecznej edukacji ekologicznej powinno być uzupełnianie działań realizowanych w ramach edukacji formalnej o przedsięwzięcia podejmowane przez różne instytucje i placówki w ramach edukacji nieformalnej. Przecież nadrzędnym celem, do którego dążymy, jest przede wszystkim wykształcenie motywacji do zdobywania wiedzy o środowisku, wrażliwości i moralnej odpowiedzialności za stan otaczającego środowiska oraz gotowości uczestniczenia w działaniach ochraniających środowisko. Dlatego w procesie dydaktyczno-wychowawczym powinno się uwzględniać przede wszystkim najbliższe otoczenie oraz częsty kontakt z przyrodą. Takie działania ułatwiają ukształtowanie w dzieciach, rodzicach oraz społeczności lokalnej odpowiednich postaw, zmierzających do podejmowania trwałych działań proekologicznych, które z czasem mogą stać się permanentnym nawykiem. Wszak człowiek 
nigdy nie przestaje się uczyć. Edukacja towarzyszy nam w różnych sferach codziennej działalności przez całe życie. Uczenie kojarzy się głównie ze szkołą, ale nie powinniśmy zaniedbywać nauki, która ma miejsce już poza jej murami. To, czego się uczymy, przyczynia się w dużym stopniu do tego, jakimi ludźmi jesteśmy. Im więcej wiadomości posiadamy, tym większa jest nasza świadomość rozwoju otaczającego nas świata, zrozumienia zjawisk, jakie wokół nas zachodzą, co z kolei pozwala nam na pełny udział w życiu społecznym.

Edukacja formalna realizowana jest w szkołach na wszystkich etapach kształcenia (przedszkola, szkoły podstawowe, szkoły średnie, szkoły wyższe). Placówki oświatowe odgrywają główną rolę w edukacji ucznia na różnych etapach nauczania, ale nie mogą być jedynym źródłem wiedzy. Pamiętając o tym, należy współdziałać z innymi instytucjami i organizacjami. Nauczyciel wykładający przedmioty przyrodnicze zobowiązany jest nawiązać kontakt z placówkami promującymi edukację ekologiczną, ponieważ bardzo ważnym aspektem rozwoju każdego człowieka jest rozbudzanie w nim wrażliwości na otaczające go środowisko i wskazanie właściwych dróg postępowania. Obecnie ogromny potencjał, ale nadal niedoceniany i mało wykorzystany w edukacji ekologicznej mają ośrodki edukacji pozaformalnej.

Przez pojęcie przyrodnicza edukacja pozaformalna rozumiemy kształcenie, szkolenie, uczenie się w zakresie przedmiotów przyrodniczych, które nie prowadzi wprost do uzyskania kwalifikacji, realizowane w ramach programów organizowanych przez różne podmioty (np. pracodawców, organizacje obywatelskie, ale także uczelnie, szkoły i osoby indywidualne) (Arévalo-Garcia et al. 2013). Praca takich ośrodków dąży przede wszystkim do popularyzacji nauk przyrodniczych lub wybranej ich dziedziny. Prezentując świat przyrody jako złożoną całość, na którą można patrzeć z różnych perspektyw, umożliwia się uczniom samodzielne badanie, doświadczanie przyrody, przybliżanie lokalnych zasobów przyrodniczych, kulturowych, społecznościowych w kontekście edukacji przyrodniczej - są one często spójne z wymaganiami ogólnymi. Może to stanowić sygnał, że pomiędzy sektorem edukacji pozaformalnej a szkołami istnieje przestrzeń wspólnych celów (Arévalo-Garcia et al. 2013).

W 2013 r. w Instytucie Badań Edukacyjnych w Warszawie opublikowano raport z badań dotyczących przyrodniczej edukacji pozaformalnej, w którym zamieszczono informację, że ośrodki przyrodniczej edukacji pozaformalnej w relacji do systemu szkolnictwa zazwyczaj przyjmują jedną z dwóch strategii:

1. współpraca ze szkołą - czyli uzupełnienie oferty i wsparcie szkoły w jej zadaniach; dopasowanie swojej oferty w kontekście treści dydaktycznych, jak i rozwijanych umiejętności;

2. odrębność od szkoły - czyli „uczenie inaczej niż szkoła”, chęć odróżnienia się od niej; brak zainteresowania realizowaniem celów dydaktycznych szkoły, ale też wykraczanie poza jej program i metody.

Podmioty te, czyli ośrodki edukacji pozaformalnej, realizują zajęcia o tematyce związanej z jednym bądź kilkoma przedmiotami przyrodniczymi, przy zastosowaniu między innymi takich form i metod, jak:

- prelekcje;

- wykłady;

- pogadanki;

- zajęcia terenowe;

- seminaria, konferencje;

- doświadczenia i obserwacje w warunkach terenowych bądź laboratoryjnych. Autorzy publikacji opracowanej i wydanej przez Instytut Badań Edukacyjnych w Warszawie twierdzą, że dobrze przygotowane i przeprowadzone zajęcia (Arévalo-Garcia et al. 2013):

- pozwalają formułować procedury badawcze i je testować (planowanie i realizacja doświadczeń/eksperymentów, obserwacji) w zakresie opisanym w celach kształcenia i zalecanych doświadczeniach oraz obserwacjach nowej 
podstawy programowej przedmiotów przyrodniczych;

- odnoszą się do umiejętności ważnych w edukacji przyrodniczej - związanych z rozumowaniem naukowym, takich jak: planowanie i realizacja doświadczeń i obserwacji, formułowanie wniosków, określanie związków przyczynowo-skutkowych, odróżnianie opinii od faktów czy popieranie swojego stanowiska rzeczowymi argumentami, opisane celami kształcenia nowej podstawy programowej przedmiotów przyrodniczych.

Wspomniany potencjał sektora edukacji pozaformalnej, jak wskazują autorzy, związany jest między innymi z nieco odmienną specyfiką niż ta charakterystyczna dla działalności szkół. Ośrodki edukacji pozaformalnej bazują na potencjale innych instytucji:

- $\quad$ szkół wyższych i ośrodków naukowych;

- jednostek Lasów Państwowych;

- parków narodowych;

- organizacji pozarządowych.

Tym samym zyskują one dostęp do zasobów i możliwości rzadziej spotykanych w szkołach, wśród których najważniejsze to (Arévalo-Garcia et al. 2013):

- kadra naukowa (pracownicy naukowi, badacze etc. niezajmujący się na co dzień zadaniami dydaktycznymi);

- kadra dydaktyczna (osoby z przygotowaniem dydaktycznym, np. nauczyciele akademiccy);

- infrastruktura (np. sale wykładowe, laboratoryjne);

- wyposażenie (np. sprzęt potrzebny do realizowania doświadczeń i obserwacji);

- baza przyrodnicza;

- możliwość prowadzenia działalności dochodowej i inwestowania w rozwój własnej placówki;

- możliwość stosowania form i metod innych niż przyjęte w szkolnej dydaktyce przedmiotów przyrodniczych w zakresie pomysłów własnych czy też wzorców zapożyczonych.
Aby edukacja ekologiczna była naprawdę skuteczna, niezbędne jest połączenie obydwu oddziaływań edukacji formalnej i nieformalnej, tak aby przekazywana wiedza i wartości miały możliwość zastosowania praktycznego w codziennym życiu. Nieformalną edukacją ekologiczną powinni zajmować się przede wszystkim: rodzina i organizacje oraz instytucje proekologiczne, ośrodki edukacji ekologicznej w miastach i na obszarach chronionych, organizacje społeczne i młodzieżowe, ośrodki kultury, ośrodki medycyny konwencjonalnej i niekonwencjonalnej, placówki opiekuńczo-wychowawcze (Kiełczewski 2001, 195).

Zarówno edukacja formalna, jak i nieformalna mają swoje zalety. Zdecydowanym plusem edukacji formalnej jest systematyczność i ciągłość przekazywanej wiedzy, natomiast walorem edukacji nieformalnej jest dobrowolność jej uczestników, co może zaowocować większymi szansami na powodzenie podejmowanych oddziaływań. W procesie edukacji nieformalnej największe znaczenie i najszerszy zasięg oddziaływania mają środki masowego przekazu: telewizja, radio oraz prasa codzienna i tygodniowa. Zagadnienia ekologiczne wciąż cieszą się dużym zainteresowaniem (Górka et al. 2001, 39). Coraz większą popularność osiągają również strony internetowe o charakterze przyrodniczym.

Aby skutecznie poprawić jakość środowiska nie tylko w skali lokalnej, trzeba nadal kontynuować wspólne wysiłki zarówno instytucji do tego powołanych, samorządów, podmiotów gospodarczych, jak i całego społeczeństwa. Żadne jednak akcje nie pomogą, jeśli ochrona środowiska nie będzie celem nadrzędnym. Różne formy edukacji związane z ochroną muszą być stale obecne w naszym otoczeniu (w szkole, biurze, domu). Tylko wtedy wytrwała i mozolna praca popularyzująca ochronę środowiska przyniesie oczekiwane efekty.

Zawsze warto pamiętać, że w przypadku ludzi dorosłych posiadają oni już bogactwo idei i doświadczeń. A na podstawie podjętych działań proekologicznych powinni 
budować nowe schematy (modeli mentalnych), które winny doprowadzić ich do uznania wartości i promowania przyrody. Szczególnie sprzyjającym czynnikiem jest świadome zaangażowanie jednostki w publiczne konstruowanie aksjologicznego paradygmatu przyrody.

Podejmowane działania na rzecz środowiska powinny zmierzać do ściślejszego powiązania procesów poznawania przyrody poprzez skupienie swych czynności wokół problemów środowiska, które wyłaniają się z określonych skupisk ludzi, analizować te kwestie, zajmować pozycje międzydyscyplinarne i globalne, które pozwalają na ich zrozumienie (Cichy 2005, 26).

W Strategii Edukacji dla Zrównoważonego Rozwoju opracowanej przez Europejską Komisję Gospodarczą ONZ czytamy, że należy popierać podnoszenie świadomości społecznej w zakresie zrównoważonego rozwoju zarówno w instytucjach oświaty formalne, jak i poprzez nie oraz społeczności, rodziny, środki masowego przekazu i organizacje pozarządowe. Dlatego problemy środowiskowe trzeba rozwiązywać, oddziałując głównie na systemy wartości, postawy i zachowania jednostek oraz grup ludzkich w stosunku do środowiska naturalnego. Edukacja społeczeństwa w tym zakresie rozumiana jest więc jako ogół oddziaływań dydaktyczno-wychowawczych oraz własnych działań ludzi, których celem jest kształtowanie harmonijnego współżycia $\mathrm{z}$ naturą, jak i zachowań w sytuacjach zagrażających bezpieczeństwu ekologicznemu. Dalszy rozwój cywilizacji nie będzie możliwy bez ochrony przyrody, która musi przenikać do wielu dziedzin ludzkiej aktywności. Ma ona na celu przewartościowanie stosunku człowieka do przyrody w kierunku równowagi.

Świadomość, wiedza, wyobrażenia, kultura i sumienie to pięć komponentów, które pełnią ważną rolę nie tylko w procesie edukacji ekologicznej, lecz przede wszystkim w kształtowaniu prawidłowych norm zachowania w codziennym obcowaniu z przyrodą, pamiętając o zasadach zrównoważonego rozwoju, ponieważ środowisko przyrodnicze jest dla społeczeństwa wartością nie tylko ekonomiczną i gospodarczą.

\section{Podsumowanie}

Zdaniem Ryszarda Sadowskiego, złożone przyczyny kryzysu ekologicznego nie ograniczają się jedynie do wymiaru technologicznego, ekonomicznego, politycznego i społecznego. Obecny stan środowiska naturalnego jest także efektem kryzysu moralnego i duchowego. W celu skutecznego przeciwdziałania kryzysowi ekologicznemu niezbędne jest włączenie w refleksję nad nim szerokiego spojrzenia filozoficznego i religijnego, które pomogą nam zrozumieć siebie, jako istoty należące do przyrody, włączone w cykl życia i zależne od środowiska naturalnego. Religia jest istotnym czynnikiem w tym procesie, ponieważ pomaga kształtować nasze postawy względem przyrody (Sadowski 2013, 81). Toteż pożądany jest zwrot w relacji człowiek-środowisko. Powstaje pilna potrzeba przewartościowania postaw względem środowiska przyrodniczego, które pozwolą człowiekowi prawidłowo w nim funkcjonować. Niezbędny jest równocześnie długookresowy punkt widzenia wyrażający się, między innymi, w działaniach na rzecz przyrody danej społeczności lokalnej. I jest to aktualnie priorytetowe wyzwanie, przed jakim staje także współczesne wychowanie, w tym wychowanie proekologiczne.

Dlatego warto, a nawet należy konkretne działania podejmowane na rzecz przyrody wzbogacać rożnymi metodami, formami i środkami, wykorzystując osiągnięcia z różnych dziedzin naukowych.

Zainicjowane przedsięwzięcia powinny pozytywnie wpłynąć na ukształtowanie systemu wartości, umożliwiając zachowanie piękna przyrody i przygotowanie społeczności lokalnej do życia zgodnie z zasadami zrównoważonego rozwoju. Wykorzystując natomiast założenia pedagogiki konstruktywistycznej, można wzbogacić ofertę działań mających na celu kształtowanie świadomości ekologicznej, w której przyroda będzie postrzegana jako wartość. 
Wartości sq podstawa, która nie tylko decyduje o życiu, lecz także określa linie postępowania i strategie, które budują życie w społeczeństwie. Nie można oddzielać od siebie wartości osobistych $i$ wartości społecznych.

(Jan Paweł II - 1985)

\section{Bibliografia}

Arévalo-Garcia, Enzo B., Irmina Buczek, Marcin Chrzanowski, Wojciech Grajkowski, Jagna Hałaczek, Krzysztof Horodecki, Magdalena Kędziora, Tomasz Nowacki, Elżbieta Barbara Ostrowska, Urszula Poziomek, Lidia Setti, Krzysztof Spalik, Martyna Studzińska, i Piotr Walicki. 2013. Dobre praktyki w przyrodniczej edukacji pozaformalnej. Warszawa: Instytut Badań Edukacyjnych. Dostęp 20.11.2020. https://wyszukiwarka.efs.men.gov.pl/ product/dobre-praktyki-w-przyrodniczej-edukacji-pozaformalnej/attachment/2349.

Bołtuć, Piotr. 2011. „Konstruktywizm w e-edukacji oraz jego krytyka." E-mentor 41(4): 48-54.

Buchcic, Elżbieta. 2017. Świętokrzyskie środowisko przyrodnicze jako wartość edukacyjno-kulturowa. Kielce: Wydawnictwo Uniwersytetu Jana Kochanowskiego.

Cichy, Danuta. 2005. „Uwarunkowania edukacji dla zrównoważonego rozwoju." W Edukacja środowiskowa wzmocnieniem zrównoważonego rozwoju, red. Danuta Cichy, 24-33. Warszawa: Wyższa Szkoła Pedagogiczna ZNP i Instytut Badań Edukacyjnych.

Domka, Ludmiła. 1998. Kryzys środowiska a edukacja dla ekorozwoju. Poznań: Wydawnictwo Naukowe Uniwersytetu im. Adama Mickiewicza.

Europejska Komisja Gospodarcza ONZ. 2008. Strategia Edukacji dla Zrównoważonego Rozwoju. Warszawa: Ministerstwo Środowiska. Dostęp 9.10.2020. http://nauczyciele.mos.gov.pl/index. php?app $=$ docs\&action= get\&iid $=1274$.

Górka, Katarzyna, Bazyli Poskrobko, i Wojciech Radecki. 2001. Ochrona środowiska. Warszawa: Polskie Wydawnictwo Ekonomiczne.

Grochowska, Irena. 2006. „Edukacja środowiskowa w zadaniach rodziny." Studia Ecologiae et Bioethicae 4: 419-435.

Hull, Zbigniew. 1984. „Świadomość ekologiczna.” Aura 11: 3-4.
Jan Paweł II. 1985. „Wy jesteście moją nadzieją. Wybór wypowiedzi Ojca Świętego Jana Pawła II do młodzieży." Dostęp 26.08.2020. https://dzieje.pl/ rozmaitosci/najbardziej-znane-cytaty-z-wystapien-jana-pawla-II.

Jan Paweł II. 2008. „Wstań i idź! Spotkanie z młodzieżą na stadionie Girland, Lyon, 5.10.1986." W Podręcznik pokolenia JP II. Ojcowskie stowo do mtodych świata, Polski i Lednicy, red. Hanna Koźmińska, 261-275. Poznań: Duszpasterstwo Akademickie Dominikanów.

Kiełczewski, Dariusz. 2001. Ekologia społeczna. Białystok: Wydawnictwo Ekonomia i Środowisko. Kopczewski, Marian, Jacek Fabisiak, i Robert Kościelniak. 2009. „Edukacja ekologiczna jako ważny komponent edukacji obronnej społeczeństwa." Zeszyty Naukowe Akademii Marynarki Wojennej 50: 63-74.

Michalak, Renata. 2005. „Konstruktywistyczna perspektywa założonego modelu edukacji elementarnej." Edukacja Elementarna Zeszyt 1 - Podstawy teoretyczne 90-106.

Nakonieczna, Beata. 2001. „Koncepcja świadomości ekologicznej w aspekcie zdrowotnym." W Edukacja ekologiczna wobec wyzwań XXI wieku, red. Jan Dębowski, 185-196. Olsztyn: Wydawnictwo Uniwersytetu Warmińsko-Mazurskiego.

Papuziński, Andrzej. 2006. „Świadomość ekologiczna w świetle teorii i praktyki. Zarys politycznego modelu świadomości ekologicznej." Problemy Ekorozwoju 1(1): 21-38.

Pilch, Tadeusz. 1993. „Środowisko lokalne - struktura, funkcje, przemiany." W Pedagogika społeczna, red. Tadeusz Pilch, i Irena Lepalczyk, 149-168. Warszawa: Uniwersytet Warszawski.

Sadowski, Ryszard. F. 2013. „Religijne źródła troski o stan środowiska przyrodniczego." Seminare. Poszukiwania Naukowe 33(1): 81-93.

Sasinowski, Henryk. 1997. Ekologia społeczna: uwarunkowania przestrzenne. Białystok: Wydawnictwo Politechniki Białostockiej.

Śliwierski, Bogusław. 2016. „Krytycznie i afirmacyjnie o edukacji konstruktywistycznej w szkolnictwie zawodowym." Dostęp 16.04.2020. http://sliwierskipedagog.blogspot.com/2016/04/krytycznie-iafirmacyjnie-o-edukacji.html.

Śniadek, Bożena. 1997. „Konstruktywistyczne podejście do nauczania o świetle i jego własnościach w okresie wczesnoszkolnym." 
W Przyroda, badania, jezzyk, red. Stanisław

Dylak, 43-44. Warszawa: Centralny Ośrodek

Doskonalenia Nauczycieli. 